\title{
The Forearm Flap - Indications, Appropriate Selection, Complications and Functional Outcome
}

\author{
Raphael Ciuman and Philipp Dost \\ Department of Otorhinolaryngology, Marienhospital Gelsenkirchen, Gelsenkirchen,
}

Germany

\section{Introduction}

A correct indication and specific knowledege in planning and harvesting free transplants are needed to minimize morbidity and maximize quality of life (QOL). Since the introduction of microvascular surgery in the 1970s, continuous surgical efforts and research were made to optimize the techniques. Consequently, there exist distinct technical modifications and alternatives that give the surgeon the possibility of adequate technique and flap-design selection dependent on the patient and situation. In the 1990s, the free forearm flap became the most utilised technique for free tissue transfer in the head and neck, with success rates of over 90\% (Soutar \& McGreagor, 1986, Swanson et al., 1990). The forearm flap was described by Yang and colleagues in 1981 for the first time and has become one of the most used transplants for reconstruction in the head and neck and a widely used transplant for other indications as well. Various complications and functional impairments at the donor site have been reported so far which are presented together with techniques to minimize them, and together with the characteristics, indications and design options of this flap.

\section{Historical description}

In 1978, Yang Guofan und Gao Yuzhi harvested a fasciocutaneous radial free flap in the Shenyang Military Hospital for the first time. This transplant got the nickname 'Chinese flap' and became the standard transplant for many indications. In 1981, they described a study of 60 patients with a single transplant loss only. Mühlbauer et al. (1982) were the first who reported upon this transplant outside of China. Stock and contributors raised an innervated flap in 1981 and in 1983, Biemer and Stock utilised an osteocutaneous pedicled transplant for thumb reconstruction. Lovie reported upon an ulnar-based forearm flap in 1984 that was classified as alternative to avoid vascular complications at the donor site by Dost and Rudofsky (1993) (Figure 1). Soutar (1983) proposed the forearm flap for reconstruction of the oral cavity, and thereafter the flap became the most utilised technique for intraoral reconstruction. Partecke et al. described a fat fascia only transplant in 1986 which results in a cosmetic appealing scar line. The defect at the recipient site was covered with a splitthickness graft. Finally, tendons and muscles were included in the transplant as well 
(Cavanagh et al., 1991). To improve the donor site morbidity, Webster and Robinson (1995) as well as S.C. Chang et al. (1996) described a suprafascial raised forearm flap in the 1990s but there were no differences demonstrable concerning the sensory outcome. Wolff and colleagues (1995) described a prefabricated fascial-split-thickness flap, and Rath and contributors (1997) widened the technical varieties by introducing a prelaminated fasciomucosal flap that was raised after six weeks. Interesting are the work of Costa and colleagues (1993) who used silicon moulds, silicone tubes and split-thickness grafts to reconstruct mouth, nose or ear, and the work of Pribaz und Fine (1994) who provided auricular cartilage into the flap to reconstruct the nose. Besides titanium mesh together with a free forearm flap can be used for reconstruction in the head and neck (Hashikawa et al., 2006; Kubo et al., 2009).
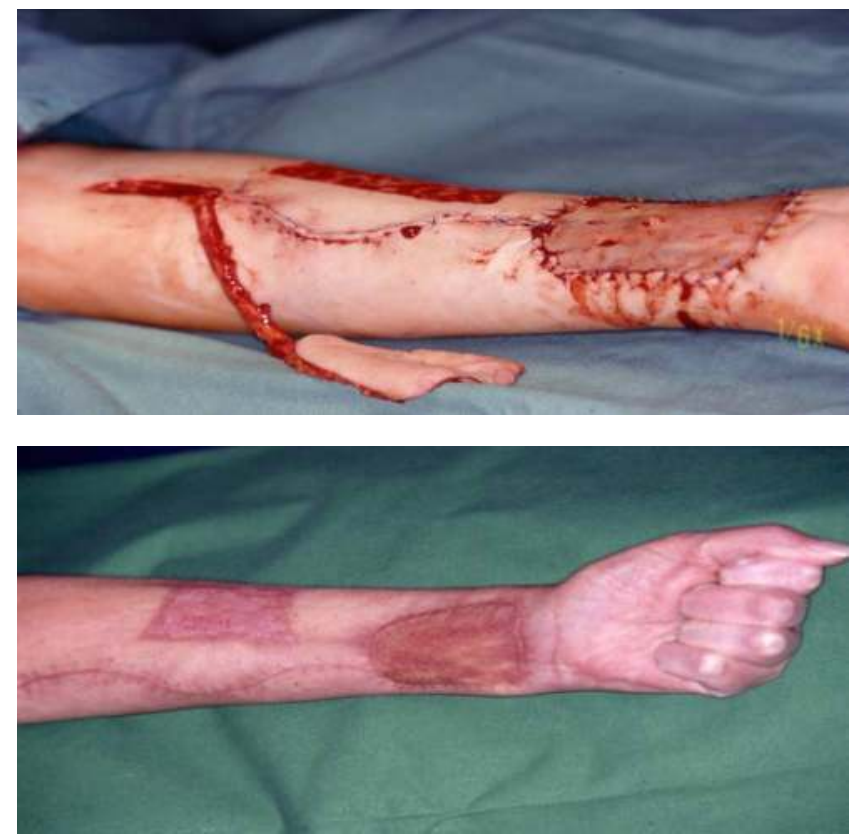

Fig. 1. The ulnar forearm free flap after harvesting and covering the donor defect with splitthickness skin graft intraoperative and three months later

To choose the functional and aesthetic most adequate and for the patient least stressful transplant, all designs fasciocutaneous/cutaneous, musculocutaneous/muscle, osteocutaneous/osteomusculocutaneous should be considered. Musculocutaneous flaps are superior to fasciocutaneous flaps for deep, poor vascularized and infected defects. Table 1 summarizes the characteristics and indications for the most adequate forearm flap designs. 


\begin{tabular}{|c|c|c|}
\hline transplant design & characteristics & indications \\
\hline $\begin{array}{l}\text { faciocutaneous } \\
\text { transplant }\end{array}$ & $\begin{array}{l}\text { standard transplant with the most } \\
\text { indications and described recipient } \\
\text { sites }\end{array}$ & $\begin{array}{l}\text { defects of the oral cavity; a } \\
\text { modeling in the } \\
\text { glossoalveolaris sulcus is easier } \\
\text { when the mandible is } \\
\text { preserved } \\
\text { tongue reconstruction for } \\
\text { defects > 50\%; superficial } \\
\text { tongue defects, especially the } \\
\text { oral part } \\
\text { pharynx reconstruction; also } \\
\text { when a muscle flap was lost } \\
\text { before } \\
\text { middle-sized defects of the } \\
\text { skull base } \\
\text { defects of the midface and orbit } \\
\text { oronasel fistulas associated } \\
\text { with palate defects } \\
\text { pretibial defects } \\
\text { hand- and arm reconstruction } \\
\text { heel defects }\end{array}$ \\
\hline $\begin{array}{l}\text { suprafascially } \\
\text { elevated transplant }\end{array}$ & $\begin{array}{l}\text { the remaining fascia decreases wound } \\
\text { healing and functional impairment } \\
\text { improved cosmetic result, but not } \\
\text { improved sensory outcome }\end{array}$ & defects of the oral cavity \\
\hline $\begin{array}{l}\text { with split-thickness } \\
\text { skin prefabricated } \\
\text { transplant }\end{array}$ & $\begin{array}{l}\text { improved cosmetic result at the } \\
\text { forearm } \\
\text { about } 10-15 \% \text { shrinking at the } \\
\text { recipient site } \\
\text { prolonged therapy }\end{array}$ & $\begin{array}{l}\text { back of the hand, because of a } \\
\text { declined tendency for oedema } \\
\text { and impaired function } \\
\text { compared to the palm } \\
\text { intraoral defects }\end{array}$ \\
\hline $\begin{array}{l}\text { prelaminated } \\
\text { fasciomucosal } \\
\text { transplant }\end{array}$ & $\begin{array}{l}\text { high compatibility at the recipient site } \\
\text { prevention of xerostomia } \\
\text { no reepitheliation and scar tissue } \\
\text { formation at the recipient site } \\
\text { silicon sheets allow an expansion of } \\
\text { about } 30-50 \% \\
\text { prolonged therapy }\end{array}$ & defects of the oral cavity \\
\hline innervated transplant & $\begin{array}{l}\text { improved sensory potency } \\
\text { prevention of aspiration }\end{array}$ & $\begin{array}{l}\text { tongue reconstruction; } \\
\text { especially the oral part } \\
\text { poor sensory potency, e.g. after } \\
\text { trigeminus resection } \\
\text { trauma with nerve damage } \\
\text { palm and sole } \\
\text { penile and urethral } \\
\text { construction }\end{array}$ \\
\hline
\end{tabular}




\begin{tabular}{|l|l|l|}
\hline transplant design & characteristics & indications \\
\hline $\begin{array}{l}\text { osteocutaneous } \\
\text { transplant }\end{array}$ & $\begin{array}{l}\text { bone up to a length of } 12 \mathrm{~cm} \text { is } \\
\text { harvestable }\end{array}$ & $\begin{array}{l}\text { mandibular reconstruction for } \\
\text { defects of up to } 9 \mathrm{~cm} \text { length; } \\
\text { especially defects of the ramus } \\
\text { and those with small bone and } \\
\text { large soft-tissue defects }\end{array}$ \\
\hline $\begin{array}{l}\text { teno- } \\
\text { musculocutaneous } \\
\text { transplant }\end{array}$ & $\begin{array}{l}\text { robust transplant, but increased } \\
\text { donor site morbidity } \\
\text { harvesting a single muscle, in most } \\
\text { cases the brachioradialis muscle, is } \\
\text { possible as well }\end{array}$ & $\begin{array}{l}\text { tongue reconstruction } \\
\text { reconstruction of the floor of } \\
\text { the mouth } \\
\text { external defects } \\
\text { infection, e.g. osteomyelitis } \\
\text { hand and elbow defects }\end{array}$ \\
\hline fat-fascia transplant & $\begin{array}{l}\text { highly vascularized tissue } \\
\text { cosmetic and functional result at the } \\
\text { donor site } \\
\text { not the adequate transplant for } \\
\text { exposed recipient sites, when } \\
\text { coverage with split-thickness graft is } \\
\text { necessary }\end{array}$ & $\begin{array}{l}\text { transplant to improve filling } \\
\text { and sliding; especially for the } \\
\text { back of the hand } \\
\text { hand and elbow } \\
\text { oral cavity }\end{array}$ \\
\hline pedicled transplant & $\begin{array}{l}\text { length of the incision is reduced } \\
\text { possibility of local anesthesia } \\
\text { but a flap fixation for about 14 days is } \\
\text { necessary }\end{array}$ & $\begin{array}{l}\text { defects of the hand or arm } \\
\text { skin defects }\end{array}$ \\
\hline
\end{tabular}

Table 1. Aspects of selecting the adequate transplant design

\section{Important anatomical variations}

Important anatomical variations in regards with the free forearm flap transfer were reported, and should be described briefly. The raised forearm flap area should not extend beyond the antecubital fossa and the radial or ulnar borders to avoid complications and sensory impairment. Yang et al. (1981) described a forearm flap of $35 \times 15 \mathrm{~cm}$, but the dimensions of the forearm transplant are limited by the bifurcation of the forearm arteries at the level of the antecubital fossa.

Both, the radial and the ulnar artery participate in the blood supply of the palmar arches but show in only $27-35 \%$ equal supply to the hand and fingers (Coleman \& Anson, 1961; Jaschintski, 1897).

In 4,31 \% (McCormack, 1953), the radial artery possesses an unusual course: a dorsal course in the distal third (Otsuka \& Terauchi, 1991), a deep course beneath the pronator teres muscle (Small \& Millar, 1985) and a superficial course on the brachioradialis muscle (Saski et al., 1999). These variations are explained by the origination of the radial artery from the anterior interosseous artery and the superficial brachial artery, respectively. In those cases a precise examination of the forearm vessels and its dominance is necessary preoperatively. Mc Cormack (1953) described in a study with 750 bodies, the origination of the radial artery from the axillary artery in $2.13 \%$, in $5.7 \%$ a superficial brachial artery that courses medial to the biceps muscle, in single cases a superficial radial artery and in $4.43 \%$ a median artery. Besides, McCormack found 
an origination of the ulnar artery from the axillary artery in $0.93 \%$. A median artery originates from the brachial artery and runs through the two bellies of the pronator teres muscle. A superficial ulnar artery is found in about 2-9\% (Devansh MS, 1996; McCormack,1953; Weathersby 1956). It runs on the flexor muscles but beneath the palmaris longus muscle and the flexor carpi ulnaris muscle. The last muscle can be absent in these cases. Radial or ulnar artery dominace can be a hint for presence of a superficial ulnar artery or median artery, which can be used for elevation instead of the dominat artery (Bell et al., 2011; Davidson et al., 2009).

The venous drainage of the forearm is guaranteed equally by the subcutaneous veins and the venae commitantes. Consequently, the subcutaneous veins can be preserved or serve for a vein graft. A transplant based on the deep venous system shows advantages in older patients (Weinzweig et al., 1994) and avoids the risk provided by veins venipunctured a few days or weeks ago (Hallock, 1986) and facilitates the prevention of cutaneous nerve damage. The superficial venous system shows high variety in size, dominance and course. Numerous anastomoses exist between the superficial veins, the deep veins and the deep and superficial venous system.

Boutros (2000) described that the lateral antebrachial cutaneous nerve supplies $61.8 \%$ of the potential flap area (range 48.3-71.6\%), the superficial radial nerve 34.6\% (range $26.8-44.1 \%$ ) and the medial antebrachial cutaneous nerve $33.8 \%$ (range $30.5-38.9 \%$ ).

\section{Characteristics}

The distinct qualities made the forearm flap to the workhorse in head and neck reconstruction. It is possible to place the flap more proximal or distal without risking the vitality of the flap. The forearm flap provides constant anatomy, is simple and rapid to harvest, possesses many kinds of alternatives in supplying arteries, veins and nerves and shows good vascularisation that results in high vitality and tolerance to radiotherapy (I.A. McGregor \& F.M. McGregor, 1986; Soutar \& Tanner, 1986). In this regards, this flap excels by its long and large-caliber vascular pedicle and nerves permitting a contralateral anastomosis and the by-passing of vascular defects, even after a neck dissection. The relative large diameter of $2 \mathrm{~mm}$ protects from thrombosis and the vessels show seldom sclerotic changes. But de Bree et al. reported a sclerotic impaired radial artery which precluded an anastomosis (DeBree et al., 2004). The flap is thin explaining its pliability, contourability, consistent volume and surface over time. Together with the possibility of harvesting innervated flaps and the relative few hair growth, these are the main reasons for satisfactory aesthetic and intraoral results. Ahcan et al. (2000) described high sensory potency compared to other flaps. The hair growth on the forearm shows some variety, whereas the ulnar side possesses less hair growth in general. To optimize the aesthetic outcome, skin color, texture, hair growth and skin thickness should be evaluated.

The ulnar artery is a little bit shorter than the radial artery. Advantages consist in a less exposed skin area, in a defect that is easier to close, less hair growth and less risk of nerve damage or numb areas. Becker und Gilbert (1988) described a flap based on the dorsal ulnar artery, which originates from the ulnar artery $2-4 \mathrm{~cm}$ proximal to the os pisiforme and has a diameter of $0.8-1.2 \mathrm{~mm}$. This variation can be utilised for a fasciocutaneous pedicled flap of $10 \times 5 \mathrm{~cm}$ in size, but has a relative short vessel length. The advantages and disadvantages of the forearm flap are summarized in Table 2. 


\begin{tabular}{|l|l|}
\hline \multicolumn{1}{|c|}{ advantages } & \multicolumn{1}{|c|}{ disadvantages } \\
\hline constant anatomy & $\begin{array}{l}\text { discontent of the cosmetic outcome of this } \\
\text { exposed area is possible }\end{array}$ \\
\hline $\begin{array}{l}\text { several altenatives in arteries, veins and } \\
\text { nerves }\end{array}$ & $\begin{array}{l}\text { necessity of a preoperative doppler } \\
\text { sonography to guarantee the blood supply } \\
\text { to the hand }\end{array}$ \\
\hline $\begin{array}{l}\text { excellent vascularisation: the lenghth of the } \\
\text { artery is 10-18 cm, the diameter about } 2 \mathrm{~mm}, \\
\text { almost no sclerotic changes; } \rightarrow \text { important at } \\
\text { surgically difficult recipient sites }\end{array}$ & $\begin{array}{l}\text { color differences between the skin of the } \\
\text { forearm and the face }\end{array}$ \\
\hline $\begin{array}{l}\text { flap thickness may be varied by flap } \\
\text { placement more distal or proximal }\end{array}$ & $\begin{array}{l}\text { a longer, more pretentious and exhausting } \\
\text { operation compared to a local defect closure }\end{array}$ \\
\hline $\begin{array}{l}\text { simple and rapid to harvest proximal as } \\
\text { well as distal }\end{array}$ & $\begin{array}{l}\text { scar tissue fixation between the recipient site } \\
\text { and the transplant may occur }\end{array}$ \\
\hline thin $\rightarrow$ no airway obstruction & \\
\hline $\begin{array}{l}\text { pliability, contourability: folding in } \\
\text { sandwich technique is possible }\end{array}$ & \\
\hline consistent volume and surface over time & \\
\hline skin with high sensory (protecting) potency & \\
\hline tolerance to radiation therapy & \multicolumn{2}{|l}{} \\
\hline $\begin{array}{l}\text { infections like osteomyelitis or a } \\
\text { osteoradionecrosis often show primary } \\
\text { wound healing because of excellent } \\
\text { vascularisation }\end{array}$ & $\begin{array}{l}\text { several skin islands can be raised at the } \\
\text { perforators }\end{array}$ \\
\hline
\end{tabular}

Table 2. Advantages and disadvantages of the forearm flap

\section{Indications}

The forearm serves for a free flap transplant and a pedicled flap as well. Because of the above mentioned advantages and in Table 1 summarized qualtities and characteristics, the forearm flap represents the first therapy option for various kinds of surgical indications with a high overall success rate (Table 3 . Complications at the recipient site). It is a highly utilised flap at pretentious recipient sites like the oral cavity, the palate, after a trauma or a tumor resection. The forearm flap replaced the pectoralis major transplant in tongue reconstruction, especially for the oral part of the tongue (Schustermann et al., 1991). The forearm flap particularly serves for the reconstruction of superficial defects. It is used for jaw reconstruction or penile and urethral reconstruction and for coverage of pretibial defects as well, as it is a thin transplant (Biemer, 1988; T.S. Chang and Hwang, 1984). An innervated radial forearm flap is raised with the lateral antebrachial cutaneous nerve and an ulnar forearm flap with the medial antebrachial cutaneous nerve. Innervated flaps could show a faster and increased sensory recovery (Santamaria et al., 1998). Nerve fibers with normal ultrastructure can be found at the recipient site immunohistochemically, in contrast to Waller degeneration and nerve fiber loss in non-innervated flaps (Katou et al., 1995). Boyd et al. (1994) and Dubner et al. (1992) could show that innervated transplants result in an 
increased sensory capacity of the flap, even improved to the surrounding tissue. The flap should not be raised, if one palmar arch is absent, if there exists an absolute artery dominance or if one forearm artery is missing. Bone should not be included, if it shows osteoporotic changes.

\begin{tabular}{|c|c|}
\hline \multicolumn{2}{|c|}{ Complications at the recipient site } \\
\hline Total & $10162641-392233$ \\
\hline transplant loss & $3-13 \% 71316253031333641$ \\
\hline partial transplant loss & $11622-3 \% 517$ \\
\hline thrombosis & $2 \% 16-9 \% 2236$ \\
\hline obstruction of vein grafts & $9 \% 19$ \\
\hline hematoma/seroma & $42133-7 \% 1624$ \\
\hline infection & $4^{16-12 \% 3341}$ \\
\hline dehiscence & $41641-12 \% 33$ \\
\hline fistula formation & $\begin{array}{l}\text { pharyngeal: } 18-32 \% 5151718293842 / 86 \% \text { close } \\
\text { spontaneously }{ }^{1} \\
\text { oral: } 0536-9 \% 163335 / 83 \% \text { close } \\
\text { spontaneously } 1\end{array}$ \\
\hline stricture, stenosis & $8120-30 \% 15$ \\
\hline reoperations & $324-19 \% 37$ \\
\hline
\end{tabular}

Table 3. Complications at the recipient site (References are listed under Annexes 9.1 References Table 3)

\section{Complications, function loss at the donor site and techniques to minimize}

Correct planning and elevation prsupposed, there will be no clinically relevant limitatations in strength, motion and hemodynamics in the forearm and hand after free forearm flap transfer. Sensory and cosmetic outcome is perceived as non-disturbing (Ciuman et al., 2007). The complication rates and the rates of function loss at the donor site are summarized in Table 4.

To optimize the functional and aesthetic outcome at the donor site, different techniques and tests can be applied. A preoperative Doppler sonography is suggested before raising the forearm flap (Dost \& Rudofsky, 1993; Dost, 2001). Cases of acute ischemia of the hand were described, although a preoperative assessment with the Allen's test was performed. An absence of a forearm vessel, one palmar arch (in about 4,5\%) (Partecke \& Buck-Gramcko, 1984), or an absolute dominance of one vessel can lead to an inadequate blood supply of the forearm and hand. Only in those cases, vascular diseases or young patients (Kropfl et al., 1995), a vein graft seems to be profitable (Meland et al., 1993). Heller et al. (2004) described a patient with finger necrosis months after the operation, caused by an absent deep palmar arch, and the subsequent reconstruction of the radial artery. Circia-Llorens et al. (1999) could prove that the remaining forearm vessels, especially the anterior interosseous artery, show an increase in diameter and flow. It could be shown that this vessel forms an anastomosis with the vessel stump of the harvested artery. 


\begin{tabular}{|c|c|}
\hline \multicolumn{2}{|c|}{ Complications at the donor site } \\
\hline total patients with complications & $14-33 \% 163741$ \\
\hline $\begin{array}{l}\text { delayed wound healing at the } \\
\text { donor site } \\
\text { necrosis above a tendon }\end{array}$ & $\begin{array}{l}\text { Suprafascial transplant: } 0-6-\% 224 \\
\text { fasciocutaneous transplant: } 8-24 \% 31621323744 \\
316-13 \% 52132\end{array}$ \\
\hline hematoma/seroma & $2^{16-7 \% 37}$ \\
\hline infection & $13 \%$ \\
\hline $\begin{array}{l}\text { radius fracture in ostoescutaneous } \\
\text { flaps }\end{array}$ & $8-43 \% 37810324143$ \\
\hline \multicolumn{2}{|c|}{ Function loss and long-time results at the donor site } \\
\hline \multicolumn{2}{|c|}{$\begin{array}{l}\text { fasciocutaneous: intact range of wrist motion in } 94.4 \% \text { and free forearm rotation in } 97.4 \% 19 \\
\text { osteocutaneous: intact range of wrist motion in } 89-90 \%^{34} \\
\text { after fractures impaired range of motion in up to } 50 \%^{3}\end{array}$} \\
\hline impaired muscle strength & $0-16 \% 11323940 ;$ after fractures: $50 \% 332$ \\
\hline unsightly scar formation ${ }^{19}$ & $\begin{array}{ll}\text { unstable scar } 10.5 \% & \text { level differences } 46.8 \% \\
\text { pigmentation disturbance } 58.4 \% & \text { strong plaster over } 18.7 \%\end{array}$ \\
\hline $\begin{array}{l}\text { mean circumference loss in } \\
\text { fasciocutaneous flaps }\end{array}$ & $1.3 \% 19$ \\
\hline discontent & $2-28 \% 112427283241$ \\
\hline
\end{tabular}

Table 4. Frequencies of complications and function loss at the donor site (References are listed under Annexes 9.2 References Table 4)

Wound healing problems can result in impaired functional outcome. A limited wrist and finger motion and decresed muscle strength can result from graft necrosis, exposed tendons, and subsequent adherent scar formation (Kröpfl et al.). A careful coverage of the tendons with flexor muscles guarantees a plain wound for the split-thickness graft. The paratenon should be preserved, the flap can be placed more proximally and the arm should be immobilized in extension to achieve an optimal wound healing. If muscle or bone is included in the flap, the wound healing is delayed and the risk of wound healing problems is increased. Vacuumtechnique (Argenta \& Morykwas, 1997) can assist wound healing in complicated cases. A short-time hyperalimentation should be considered in tumor patients as well.

A careful preparation, together with an oblique incision to avoid dead space, especially when thick subcutaneous tissue is present, avoid hematoma and seroma formation and leads to an improved healing of the split-thickness graft.

The fracture rate after an osteocutaneous ulnar or radial transplant varies between 8 and $43 \%$ but can be decreased by physiotherapy, harvesting not more than one third of the bone, performing a „boat-shaped, osteotomy, that decreases the stress concentration effect by $5 \%$ (Meland et al., 1992), and immobilizing the arm in extension for 6-8 weeks (Partecke \& BuckGramcko, 1984). A control radiography should be performed before and after the operation.

All different kinds of objective (quantitative, qualitative, dissociated) and subjective sensory impairment were described subsequently to the free forearm flap transfer. But in general, the patient states that he is not affected in his daily activities. Table 5 summarizes the frequencies of disturbed sensory modalities and qualities after free forearm flap transfer. 


\begin{tabular}{|c|c|c|c|}
\hline & Type & Freq & rency \\
\hline \multirow[t]{2}{*}{ quantitative } & $\begin{array}{l}\text { hypoesthesia, hypopathia, } \\
\text { hypoalgesia }\end{array}$ & $\begin{array}{l}16-75 \% 35911122124 \\
324143\end{array}$ & $\begin{array}{l}023-32 \% 1132 \\
77.1^{44}-86.5 \% 19 \text { of } \\
\text { the defects } \\
\text { covered with } \\
\text { split-thickness } \\
\text { grafts } \\
8,6 \% \text { of those } \\
\text { areas are } \\
\text { anesthetical }{ }^{44}\end{array}$ \\
\hline & $\begin{array}{l}\text { hyperesthesia, hyperalgesia, } \\
\text { hyperpathia (neuroma) }\end{array}$ & $5^{3}-14 \% 111$ & $\begin{array}{l}119-10 \% 31132 \\
8.6 \% 44 \text { of the } \\
\text { defects covered } \\
\text { with spilt- } \\
\text { thickness grafts }\end{array}$ \\
\hline \multirow[t]{2}{*}{ qualitative } & allesthesia & sporadically, $<3 \%$ & $\begin{array}{l}\text { only } 10^{11}-12.4 \% 19 \\
\text { of the patients } \\
\text { have a two-point } \\
\text { discrimination on } \\
\text { the defects } \\
\text { covered with } \\
\text { split-thickness } \\
\text { grafts }\end{array}$ \\
\hline & $\begin{array}{l}\text { causalgia/reflex sympathetic } \\
\text { dystrophy }\end{array}$ & sporadically, $<3 \%$ & sporadically, $<3 \%$ \\
\hline dissociated & temperature discrimination & \multicolumn{2}{|c|}{$\begin{array}{l}\text { cold intolerance with improvement } \\
\text { with time 0-32\%136711 } 121424324344 \\
\text { (climate dependency) } \\
\text { single cases of heat intolerance }{ }^{39}\end{array}$} \\
\hline \multirow[t]{5}{*}{ subjective } & itching & \multirow{5}{*}{$\begin{array}{l}\text { initially } \\
\text { manifesting } \\
\text { subjective sensory } \\
\text { dysfunction often } \\
\text { signals nerve } \\
\text { regeneration or } \\
\text { nerve ingrowth }\end{array}$} & \multirow[t]{2}{*}{$14{ }^{12}-19.6 \% 1119$} \\
\hline & \multirow{2}{*}{$\begin{array}{l}\text { dysesthesia } \\
\text { hypersensitiveness }\end{array}$} & & \\
\hline & & & \multirow{2}{*}{$\begin{array}{l}1011-40.6 \% 19 \\
29.5 \%, \text { but in only } \\
1,1 \% \\
\text { pronounced } 19^{19}\end{array}$} \\
\hline & \multirow[t]{2}{*}{ scar pain } & & \\
\hline & & & $\begin{array}{l}311-36 \% ; 6.5 \% \text { of } \\
\text { them are distinct } \\
\text { or strong } 19\end{array}$ \\
\hline
\end{tabular}

Table 5. Frequencies of sensory impairment at the donor site after fasciocutaneous forarm flap transfer (References are listed under Annexes 9.3 References Table 5) 
Initially, sensory disturbances can be found in $17-75 \%$ but decrease during the next months. Hypersensitiveness, paresthesias and dysesthesias can signal sensory regeneration. However, hyperesthesia and neuralgia could signal nerve section, but decrease in the following months, too. Together with pain due to neuroma formation or causalgia, they are difficult to treat, what underlines the importance of careful preparation and good vascularisation to prevent perineural scar formation and assist nerve regeneration. Richardson et al. (1997) described four neuromas in a group of 86 patients making a surgical neuroma excision necessary (Anthony et al., 1994). The nerve endings should be covered with muscle and not come into contact with the split-thickness skin graft. Although it is not possible to preserve the cutaneous nerves in each case, e.g. the lateral antebrachial cutaneous nerve or the superficial radial nerve, an ulnar-based flap and the limitated dimension to the radial or ulnar border can improve sensory outcome (Lovie et al., 1984).

It is not surprising that women are more pretentious with regard to the aesthetic outcome at the forearm. Alternatives for achieving the optimal cosmetic result are dicussed in Table 1 and the following paragraph. Hülsbergen-Krüger et al. (1996) described in their group of 267 patients after closing the defect with split-thickness graft, reduced pigmentation in $43.4 \%$, increased pigmentation in $15 \%$, level differences $>0.1 \mathrm{~cm}$ in $46.8 \%$, but in only $12 \%$ $>0.4 \mathrm{~cm}$, an unstable scar in $10.5 \%$ and an adherence of the defect in $18.7 \%$. Adequate compression, first with dressings and later with compression stockings, and the application of $2 \mathrm{~mm}$ metal plates can assist the wound healing.

\section{Closure of the donor site}

The most utilised technique to close the defect at the donor site is the coverage with 0.2-0.6 mm split-thickness skin grafts. Lutz and colleagues described a success rate of $98 \%$ compared with $84 \%$ in full skin grafts (Lutz et al., 1999). However, if the wound is not plain, e.g. above a tendon, opposite results can be found as well. Other studies showed a complete loss of the split-thickness skin graft in 8 (Evans et al., 1994) -16\% (Richardson et al., 1997), a partial loss in 16-35\% (Bardsley et al., 1990; A.D. McGregor, 1987; Meland et al., 1993, Richardson et al., 1997; Swanson et al., 1990; Timmons et al., 1986), and a loss of splitthickness skin grafts in suprafascial elevated flaps in 0-4\% (Avery et al., 2001, Chang et al., 1996, Lutz et al., 1999). Patients are more content with full skin grafts than with splitthickness grafts: $92 \%$ to $57 \%$ (Lutz et al., 1999). Defects up to $4 \times 8 \mathrm{~cm}$ in size can be closed with a V-Y transposition flap (Elliot et al., 1996). Enough skin should be disposable to avoid limitations in wrist extension, chronic lymphatic edema, sensory disturbance of the forearm or necrosis. Another alternative of closure is skin expansion that can be primary (Bardsley et al., 1990; Herndl \& Mühlbauer, 1986) or secondary. Because of wound healing problems in about 30\%, Hallock (1988) recommends for the secondary skin expansion a coverage with split-thickness skin graft, in the first instance. After six weeks, it is possible to begin the expansion. A secondary shrinking and a thinning out of the subcutaneous tissue needs to be considered. The skin area of the harvested transplant should never be expanded as a shrinking at the recipient site would be the consequence. The flap preparation should begin from the region opposite to the expanded area to avoid shrinking during the operation. However, a disturbance of the microcirculation with venous congestion might still occur. Dehiscence after expansion was described in up to 40\% (Bootz et al., 1993; Lovie et al., 1984), but other studies showed complication rates of less than 10\% (Makitie et al., 1997). 


\section{Conclusion}

Microvascular surgery often presents the only possibility to reach satisfactory functional, and cosmetic outcomes and to achieve acceptable quality of life for reconstruction in the head and neck. Due to distinct charactersitics the forearm flap is one of the most used transplants for reconstruction in the head and neck and a widely used transplant for other indications as well. Correct planning and elevation presupposed the flap success rates average at least $90 \%$ with no relevant limitations in strength, motion and hemodynanics in the forearm or hand and non-disturbing sensory and cosmetic outcome at the donor site.

\section{Annexes}

\subsection{References Table 3}

Complications at the recipient site

\subsection{References Table 4}

Frequencies of complications and function loss at the donor site

\subsection{References Table 5}

Frequencies of sensory impairment at the donor site after fasciocutaneous forarm flap transfer

[1] Anthony JP, Singer MI, Deschler DG. Dougherty ET, Reed CG \& Kaplan MJ. (1994). Long-term functional results after pharyngoesophageal reconstruction with the radial forearm free flap. Am J Surg, 168(5), pp. 441-445. ISSN: 0002-9610

[2] Avery CM, Pereira J \& Brown AE. (2001). Suprafascial dissection of the radial forearm flap and donor site morbidity. Int J Oral Maxillofac Surg, 30(1), pp. 42-48. ISSN: 0901-5027

[3] Bardsley AF, Soutar DS, Elliot D \& Batchelor AG. (1990). Reducing morbidity in the radial forearm flap donor site. Plast Reconstr Surg, 86(2), pp. 287-294. ISSN: 00321052

[4] Becker C \& Gilbert A. (1988) The ulnar flap. (German). Handchir Mikrochir Plast Chir, 20(4), pp. 180-183. ISSN: 0722-1819

[5] Blackwell KE. (1999). Unsurpassed reliability of free flaps for head and neck reconstruction. Arch Otolaryngol Head Neck Surg, 125(3), pp. 295-299. ISSN: 08864470

[6] Bootz F, Becker D \& Fliesek J. (1993). Functional results and survival of tumor patients after reconstruction of the mouth cavity and oropharynx using a microvascular radial forearm flap. (German). HNO, 41(8), pp. 542-552. ISSN: 0017-6192

[7] Boorman JG, Brown JA \& Sykes PJ. (1987). Morbidity in the forearm flap donor arm. Br J Plast Surg, 40(2), pp. 207-212. ISSN: 0007-1226

[8] Boyd JB, Rosen I, Rotstein L, Freeman J, Gullane P, Manktelow R \& Zuker R. (1990). The iliac crest and the radial forearm flap in vascularized oromandibular reconstruction. Am J Surg, 159(3), pp. 301-308. ISSN:0002-9610 
[9] Brown MT, Couch E \& Huchton DM. (1999). Assessment of donor-site function morbidity from radial forearm fasciocutaneous free flap harvest. Arch Otolaryngol Head Neck Surg, 125(12), pp. 1371-1374. ISSN: 0886-4470

[10] Christie DR, Duncan GM \& Glasson DW. (1994). The ulnar artery free flap: the first 7 years. Plast Reconstr Surg, 93(3), pp. 547-551. ISSN: 0032-1052

[11] Ciuman R, Mohr C, Kröger K \& Dost P. (2007). The forearm flap: assessment of functional and aesthetic outcomes and quality of life. Am J of Otolaryngol, 28(6), pp. 367-374. ISSN: 0196-0709

[12] DeBree R, Hartley C, Smeele LE, Kuik DJ, Quak JJ \& Leemans CR. (2004). Evaluation of Donor Site Function and Morbidity of the fasciocutaneous radial forearm flap. Laryngoscope, 114(11), pp. 1973-1976. ISSN: 1531-4995

[13] Dost P. (2001). The ulnar artery or the radial artery can be used alternatively in the free underarm flap. (German). Laryngorhinootologie, 80(3), pp. 152-155. ISSN: 0935-8943

[14] Dost P. \& Rudofsky G. (1993). Doppler ultrasonography as a pre-operative aid to base the forearm flap on the radial or ulnar artery. Clin Otolaryngol Allied Sci, 18(5), pp. 355-358. ISSN: $1749-4478$

[15] Endo T \& Nakayama Y. (1997). Pharyngoesophageal reconstruction: a clinical comparison between free tensor fasciae latae and radial forearm flaps. J Reconstr Microsurg, 13(2), pp. 93-97. ISSN: 0743-684X

[16] Evans GR, Schustermann MA, Kroll SS, Miller MJ, Reece GP, Robb GL, Ainslie N. (1994). The radial forearm free flap for head and neck reconstruction: a review. Am J Surg, 168(5), pp. 446-450. ISSN: 0002-9610

[17] Hagen R. (1991). Stimmrehabilitation mit dem Unterarmlappen. (German). In: Konturen der plastischen Chirurgie, Greulich M, Wangerin K, Gubisch W, eds. pp. 55-62, Hans Marseille Verlag, ISBN: 3886160440, München

[18] Harii K, Ebihara S, Ono I, Saito H, Terui S \& Takato T. (1985). Pharyngoesophageal reconstruction using a fabricated forearm free flap. Plast Reconstr Surg, 75(4), pp. 463-476. ISSN: 0032-1052

[19] Hülsbergen-Krüger S, Müller K \& Partecke BD. (1996). Donor site defect after removal of free and pedicled forearm flaps: functional and cosmetic results. (German). Handchir Mikrochir Plast Chir, 28, 82(2), pp. 70-75. ISSN: 0722-1819

[20] Kelly KE, Anthony JP \& Singer M. (1994). Pharyngoesophageal reconstruction using the radial forearm fasciocutaneous free flap: Preliminary results. Otolaryngol Head Neck Surg, 111(1), pp. 16-24. ISSN: 0194-5998

[21] Kröpfl A, Helmberger R, Gasperschlitz F, Moosmüller W \& Hertz H. (1995). Donor site morbidity following radial forearm flap.(German). Handchir Mikrochir Plast Chir, 27(2), pp. 72-77. ISSN: 0722-1819

[22] Kroll SS, Schustermann MA, Reece GP, Miller MJ, Evans GR, Robb GL \& Baldwin BJ. (1996). Choice of flap and incidence of free flap success. Plast Reconstr Surg, 98(3), pp. 459-463. ISSN: 0032-1052

[23] Lovie MJ, Duncan GM \& Glasson DW. (1984). The ulnar artery forearm flap. Br J Plast Surg, 37(4), pp. 486-492. ISSN: 0007-1226

[24] Lutz BS, Chang SCN, Chuang SS \& Wei FC. (1999). Supra-fascial elevated free forearm flap-indications, surgical technique and follow-up examination of the donor site defect. (German). Handchir Mikrochir Plast Chir, 31(1), pp. 10-14, ISSN: 0722-1819 
[25] Makitie A, Aitasalo K, Pukander J, VirtaniemiJ, Hyrynkangas K, et al. (1997). Microvascular free flaps in head and neck cancer surgery in Finland 1986-1995. Acta Otolaryngol Suppl, 529, pp. 245-246. ISSN: 0365-5237

[26] Matthew WR \& Hochman M. (2000). Length of stay after free flap reconstruction of the head and neck. Laryngoscope, 110(2), pp. 210-216. ISSN: 1531-4995

[27] McGregor AD. (1987). The free radial forearm flap: The management of the secondary defect. Br J Plast Surg, 40(1), pp. 83. ISSN: 0007-1226

[28] Meland BN, Core GB \& Hoverman VR. (1993). The radial forearm flap donor site: Should we vein graft the artery? A comparative study. Plast Reconstr Surg, 91(5), pp. 865-870. ISSN: 0032-1052

[29] Percival NJ \& Early MJ. (1989). Pharyngostome closure using the radial forearm free flap. Br J Plast Surg, 42(4), pp. 473-477. ISSN: 0007-1226

[30] Plinkert PK, Bootz F \& Zenner HP. Differential indications of free and pedicled transplants in reconstructive surgery in the head and neck area. (1993).(German). Laryngorhinootologie, 72(11), pp. 537-544. ISSN: 0935-8943

[31] Remmert S. (1995). Microvascular anastomoses in reconstructive head and neck surgery. (German). Laryngorhinootologie, 74(4), pp. 233-237. ISSN: 0935-8943

[32] Richardson D, Fisher, SE, Vaughan, ED \& Brown JS. (1997). Radial forearm flap donorsite complications and morbidity: A prospective study. Plast Reconstr Surg, 99(1), pp. 109-115. ISSN: 0032-1052

[33] Schustermann MA, Kroll SS, Weber RS, Byers RM, Guillamondegqui O \& Goepfert H. (1991). Intraoral soft tissue reconstruction after cancer ablation: A comparison of the pectoralis major flap and the free radial forearm flap. Am J Surg, 162(4), pp. 397399. ISSN: 0002-9610

[34] Smith AA, Bowen CV, Rabaczak T \& Boyd JB. (1994). Donor site deficit of the osteocutaneous radial forearm flap. Ann Plast Surg, 32(4), pp. 372-376. ISSN: 01487043

[35] Soutar DS. (1989). Radial forearm flaps. In: Microsurgical reconstruction of the head and neck, Baker SR, editor. pp. 64-76. Churchill Livingstone, ISBN: 0443085870, New York

[36] Soutar DS \& McGregor IA. (1986). The radial forearm flap in intraoral reconstruction: The experience of 60 consecutive cases. Plast Reconstr Surg, 78(1), pp. 1-8. ISSN: 0032-1052

[37] Stark B, Nathanson A, Heden P \& Jernbeck J. (1998). Results after resection of intraoral cancer and reconstruction with the free radial forearm flap. ORL J Otorhinolaryngol Relat Spec, 60(4), pp. 212-217. ISSN: 0301-1569.

[38] Su WF, Chen SG \& Sheng H. (2002). Speech and swallowing function after reconstruction with a redial forearm free flap or a pectoralis major flap for tongue cancer. J Formos Med Assoc, 101(7), pp. 472-477. ISSN: 0929-6646

[39] Suominen S \& Asko-Seljavaara S. (1996). Thermography of hands after a radial forearm flap has been raised. Scand J Plast. Reconstr Hand Surg, 30(4), pp. 307-314. ISSN: 0284-4311

[40] Suominen S, Ahovuo J \& Asko-Seljavaara S. (1996). Donor site morbidity of radial forearm flaps. Scand J Plast. Reconstr Hand Surg, 30(1), pp. 57-61. ISSN: 0284-4311 
[41] Swanson E, Boyd JB \& Manktelow RT. (1990). The radial forearm flap: Reconstructive applications and donor-site defects in 35 consecutive patients. Plast Reconstr Surg, 85(2), pp. 258-266. ISSN: 0032-1052

[42] Takato T, Harii K, Ebihara S, Ono I, Yoshizumi T \& Nakatsuka T. (1987). Oral and pharyngeal reconstruction using the free forearm flap. Arch Otolaryngol Head Neck Surg, 113(8), pp. 873-879. ISSN: 0886-4470

[43] Timmons MJ, Missotten FEM, Poole MD \& Davies DM. (1986). Complications of radial forearm flap donor sites. Br J Plast Surg, 39(2), pp. 176-178. ISSN: 0007-1226

[44] Toschka H, Feifel H, Erli, HJ, Minkenberg R, Paar O \& Riediger D. (2001). Aesthetic and functional results of harvesting radial forearm flap, especially with regard to hand function. Int J Oral Maxillofac Surg, 30(1), pp. 42-48. ISSN: 0901-5027

\section{References}

Ahcan U, Arnez Z \& Kristian A. (2000). Physiological differences for distinct somatic sensory modalities and sweating among the donor sites of cutaneous and fasciocutaneous free flaps. Acta Chir Plast, 42(1), pp. 7-12. ISSN:0001-5423

Anthony JP, Singer MI, Deschler DG. Dougherty ET, Reed CG \& Kaplan MJ. (1994). Longterm functional results after pharyngoesophageal reconstruction with the radial forearm free flap. Am J Surg, 168(5), pp. 441-445. ISSN: 0002-9610

Argenta LC \& Morykwas MJ. (1997). Vacuum-assisted closure: a new method for wound control and treatment: clinical experience. Ann Plast Surg, 38(6), pp. 563-576. ISSN: 0148-7043

Avery CM, Pereira J \& Brown AE. (2001). Suprafascial dissection of the radial forearm flap and donor site morbidity. Int J Oral Maxillofac Surg, 30(1), pp. 42-48. ISSN: 09015027

Bardsley AF, Soutar DS, Elliot D \& Batchelor AG. (1990). Reducing morbidity in the radial forearm flap donor site. Plast Reconstr Surg, 86(2), pp. 287-294. ISSN: 0032-1052

Becker C \& Gilbert A. (1988) The ulnar flap. (German). Handchir Mikrochir Plast Chir, 20(4), pp. 180-183. ISSN: 0722-1819

Bell RA, Schneider DS \& Wax MK. (2011). Superficial ulnar artery: a contraindication to radial forearm free tissue transfer. Laryngoscope, 121(5), pp. 933-936, ISSN: 15314995

Biemer E. (1988). Penile construction by the radial arm flap. Clin Plast Surg, 15(3), pp. 425430. ISSN: 0094-1298

Biemer E \& Stock W. (1983). Total thumb reconstruction: A one-stage reconstruction using an osteocutaneous forearm flap. Br J Plast Surg, 36(1), pp. 52-55. ISSN: 0007-1226

Bootz F, Becker D \& Fliesek J. (1993). Functional results and survival of tumor patients after reconstruction of the mouth cavity and oropharynx using a microvascular radial forearm flap. (German). HNO, 41(8), pp. 542-552. ISSN: 0017-6192

Boutros S, Yuksel E, Weinfeld AB, Alford EL \& Netscher DT. (2000). Neural anatomy of the radial forearm flap. Ann Plast Surg, 44(4), pp. 375-380. ISSN: 0148-7043

Boyd B, Mulholand S, Gullane P, Irish J, Kelly L, Rotstein L \& Brown D. (1994). Reinnervated lateral antebrachial cutaneous neurosome flaps in oral reconstruction. Plast Reconstr Surg, 93(7), pp. 1350-1362. ISSN: 0032-1052 
Cavanagh S, Pho, RW \& Kour AK. (1991). A composite neuro-teno-cutaneous forearm flap in the one-stage reconstruction of a large defect of the soft tissue around the ankle. $J$ Reconstr Microsurg, 7(4), pp. 323-329. ISSN: 0743-684X

Chang SC, Miller, G, Halbert CF, Yang KH, Chao WC \& Wei FC. (1996). Limiting donor site morbidity by suprafascial dissection of the radial forearm flap. Microsurgery, 17(3), pp. 136-140. ISSN: 1098-2752.

Chang TS \& Hwang WY. (1984). Forearm flap in one-stage reconstruction of the penis. Plast Reconstr Surg, 74(2), pp. 251-258. ISSN: 0032-1052

Circia-Llorens G, Gomez-Cia T \& Talegon-Melendez A. (1999). Analysis of flow changes in forearm arteries after raising the radial forearm flap: a prospective study using colour duplex imaging. Plast Reconstr Surg, 52(2), pp. 440-44. ISSN: 0032-1052

Ciuman R, Mohr C, Kröger K \& Dost P. (2007). The forearm flap: assessment of functional and aesthetic outcomes and quality of life. Am J of Otolaryngol, 28(6), pp. 367-374. ISSN: 0196-0709

Coleman SS \& Anson BJ. (1961). Arterial patterns in the hand based upon a study of 650 specimen. Surg Gynec Obstet, 113, pp. 409-424. ISSN: 0039-6087

Costa H, Cunha C, Guimaraes I, Comba S, Malta A \& Lopes A. (1993). Prefabricated flaps for the head and neck: a preliminary report. Br J Plast Surg, 46(3), pp. 223-227. ISSN: 0007-1226

Davidson JS \& Pichora DR. (2009). Median artery flap. Ann Plast Surg, 62(6), pp. 627-629. ISSN: 0148-7043

DeBree R, Quak JJ, Kummer JA, Simsek S \& Leemans CR. (2004). Severe atherosclerosis of the radial artery in a free radial forearm flap precluding its use. Oral Oncol, 40(1), pp. 99-102. ISSN: 1368-8375

Devansh MS. (1996). Superficial ulnar artery flap. Plast Reconstr Surg, 97(2), pp. 420-426. ISSN: 0032-1052

Dost P. (2001). The ulnar artery or the radial artery can be used alternatively in the free underarm flap. (German). Laryngorhinootologie, 80(3), pp. 152-155. ISSN: 0935-8943

Dost P. \& Rudofsky G. (1993). Doppler ultrasonography as a pre-operative aid to base the forearm flap on the radial or ulnar artery. Clin Otolaryngol Allied Sci, 18(5), pp. 355358. ISSN: 1749-4478

Dubner S \& Heller KS. (1992). Reinnervated radial forearm free flaps in head and neck reconstruction. J Reconstr Microsurg, 8(6), pp. 467-470. ISSN: 0743-684X

Elliot D, Bardsley AF, Batchelor AG \&Soutar DS. (1996). Direct closure of the radial forearm flap donor defect. Br J Plast Surg, 41(4), pp. 354-357. ISSN: 0007-1226

Evans GR, Schustermann MA, Kroll SS, Miller MJ, Reece GP, Robb GL, Ainslie N. (1994). The radial forearm free flap for head and neck reconstruction: a review. Am J Surg, 168(5), pp. 446-450. ISSN: 0002-9610

Hallock GG. (1986). Caution in using the Chinese radial forearm flap. Plast Reconstr Surg, 77, pp. 164. ISSN: 0032-1052

Hallock GG. (1988). Refinement of the radial forearm flap donor site using skin expansion. Plast Reconstr Surg, 81(1), pp. 21-25. ISSN: 0032-1052

Hashikawa K, Tahara S, Ishida H, Yokoo S, Sanno T, Terashi H \& Nibu K. (2006). Simple reconstruction with titanium mesh and radial forearm flap after globe-sparing total maxillectomy: a 5-year follow-up study. Plast Reconstr Surg, 117(3), pp. 963-967. ISSN: 0032-1052 
Heller F, Wei W \& Wei, FC. (2004). Chronic arterial insufficiency of the hand with fingertip necrosis 1 year after harvesting a radial forearm free flap. Plast Reconstr Surg, 114(3), pp. 728-731. ISSN: 0032-1052

Herndl E \& Mühlbauer W. (1986). Direct closure of donor defects of the radial flap by preliminary stretching of the skin with a skin expander. (German). Handchir Mikrochir Plast Chir, 18(5), pp. 289-290. ISSN: 0722-1819

Hülsbergen-Krüger S, Müller K \& Partecke BD. (1996). Donor site defect after removal of free and pedicled forearm flaps: functional and cosmetic results. (German). Handchir Mikrochir Plast Chir, 28, 82(2), pp. 70-75. ISSN: 0722-1819

Jaschintski SN. 1897. Morphologie und Topographie des Arcus volaris sublimus und profundus des Menschen. (German). Anat Hefte, 7:163-188. ISSN: 0177-5154

Katou F, Shirai N, Kamakura S, Ohki H, Motegi K, Andoh N, Date F \& Nagura H. (1995). Intraoral reconstruction with innervated radial forearm flap. Oral Surg Oral Med Oral Pathol, 80(6), pp. 638-644. ISSN: 1079-2104

Kröpfl A, Helmberger R, Gasperschlitz F, Moosmüller W \& Hertz H. (1995). Donor site morbidity following radial forearm flap.(German). Handchir Mikrochir Plast Chir, 27(2), pp. 72-77. ISSN: 0722-1819

Kubo T, Tomita K, Takada A, Yano K \& Hosokawa K. (2009). Reconstruction of adult auricular defect with thin titanium mesh and prelaminated free radial forearm flap. Scand J Plast Reconstr Surg Hand Surg, 43(1), pp. 54-57. ISSN: 0284-4311

Lovie MJ, Duncan GM \& Glasson DW. (1984). The ulnar artery forearm flap. Br J Plast Surg, 37(4), pp. 486-492. ISSN: 0007-1226

Lutz BS, Chang SCN, Chuang SS \& Wei FC. (1999). Supra-fascial elevated free forearm flapindications, surgical technique and follow-up examination of the donor site defect. (German). Handchir Mikrochir Plast Chir, 31(1), pp. 10-14, ISSN: 0722-1819

Makitie A, Aitasalo K, Pukander J, VirtaniemiJ, Hyrynkangas K, et al. (1997). Microvascular free flaps in head and neck cancer surgery in Finland 1986-1995. Acta Otolaryngol Suppl, 529, pp. 245-246. ISSN: 0365-5237

McGregor AD. (1987). The free radial forearm flap: The management of the secondary defect. Br J Plast Surg, 40(1), pp. 83. ISSN: 0007-1226

McGregor IA \& McGregor FM. (1986). Cancer of the face and mouth: Pathology and Management for Surgeons. pp.51-53, Churchill Livingstone, ISBN: 0443024553, Edinburgh

McCormack L, Cauldwell EW \& Anson BJ. (1953). Brachial and antebrachial arterial patterns. Surg Gynec Obstet, 96(1), pp. 43-54. ISSN: 0039-6087.

Meland NB, Maki S, Chao EY \& Rademaker B. (1992). The radial forearm flap: A biomechanical study of donor-site morbidity utilizing sheep tibia. Plast Reconstr Surg, 90(5), pp. 763-773. ISSN: 0032-1052

Meland BN, Core GB \& Hoverman VR. (1993). The radial forearm flap donor site: Should we vein graft the artery? A comparative study. Plast Reconstr Surg, 91(5), pp. 865-870. ISSN: 0032-1052

Mühlbauer W, Herndl E \& Stock W. (1982). The forearm flap. Plast Reconstr Surg, 70(3), pp. 336-342. ISSN: 0032-1052

Otsuka T \& Terauchi M. (1991). An anomaly of the radial artery-relevance for the forearm flap. Br J Plast Surg, 44(5), pp. 390-391. ISSN: 0007-1226 
Partecke BD \& Buck-Gramcko D. (1984). Free forearm flap for reconstruction of soft tissue defect concurrent with improved peripheral circulation. J Reconstr Microchir, 1(1), pp. 1-6. ISSN: 0743-684X

Partecke BD, Buck-Gramcko D \& Pachnucki A. (1986). Use of a fascia flap of the forearm in soft tissue defects of the extremities. (German). Handchir Mikrochir Plast Chir, 18(6), pp. 353-355. ISSN: 0722-1819

Pribaz JJ \& Fine NA. (1994). Prelamination: defining the prefabricated flap-a case report and review. Microsurgery, 15(9), pp. 618-623. ISSN: 1098-2752

Rath T, Millesi W, Millesi-Schobel G, Lang S, Glaser C \& Todoroff B. (1997). Mucosal prelaminated flaps for physiological reconstruction of intraoral defects after resection. Br J Plast Surg, 50(5), 303-307. ISSN: 0007-1226

Richardson D, Fisher, SE, Vaughan, ED \& Brown JS. (1997). Radial forearm flap donor-site complications and morbidity: A prospective study. Plast Reconstr Surg, 99(1), pp. 109-115. ISSN: 0032-1052

Santamaria E, Wei FC, Chen IH \& Chuang DC. (1998). Sensation recovery on innervated radial forearm flap for hemiglossectomy reconstruction by using different recipient nerves. Plast Reconstr Surg, 103(2), pp. 450-457. ISSN: 0032-1052

Saski K, Nozaki M, Aiba H, \& Isono N. (1999). A rare variant of the radial artery: clinical considerations in raising a radial forearm flap. Br J Plast Surg, 53(5), pp. 445-447. ISSN: 0007-1226

Schustermann MA, Kroll SS, Weber RS, Byers RM, Guillamondegqui O \& Goepfert H. (1991). Intraoral soft tissue reconstruction after cancer ablation: A comparison of the pectoralis major flap and the free radial forearm flap. Am J Surg, 162(4), pp. 397399. ISSN: 0002-9610

Small JO \& Millar R. (1985). The radial forearm flap: an anomaly of the radial artery. $\mathrm{Br} J$ Plast Surg, 38(4), pp. 501. ISSN: 0007-1226

Soutar DS \& McGregor IA. (1986). The radial forearm flap in intraoral reconstruction: The experience of 60 consecutive cases. Plast Reconstr Surg, 78(1), pp. 1-8. ISSN: 00321052

Soutar DS \& Tanner NSB. (1986). The radial forearm flap in managing soft tissue injuries of the hand. Br J Plast Surg, 37(1), pp. 18-26. ISSN: 0007-1226

Stock W, Mühlbauer W \& Biemer E. (1981). The neurovascular forearm island flap. (German). Z Plast Chir, 5(3), pp. 158-165. ISSN: 0342-7978

Swanson E, Boyd JB \& Manktelow RT. (1990). The radial forearm flap: Reconstructive applications and donor-site defects in 35 consecutive patients. Plast Reconstr Surg, 85(2), pp. 258-266. ISSN: 0032-1052

Timmons MJ, Missotten FEM, Poole MD \& Davies DM. (1986). Complications of radial forearm flap donor sites. Br J Plast Surg, 39(2), pp. 176-178. ISSN: 0007-1226

Weathersby HT. (1956). Unusual variation of the ulnar artery. Anat Rec, 124(2), pp. 245-248. ISSN: 0003-276X

Webster HR \& Robinson DW. (1995). The radial forearm flap without fascia and other refinements. Eur J Plast Surg, 18, pp. 11-13. ISSN: 0930-343X

Weinzweig N, Chen L \& Chen ZW. (1994). The distally based radial forearm fasciocutaneous flap with preservation of the radial artery: An anatomic and clinical approach. Plast Reconstr Surg, 94(5), pp. 675-684. ISSN: 0032-1052 
Wolff KD, Ervens J \& Hoffmeister B. (1995). Improvement of the radial forearm donor site by prefabrication of fascial-split-thickness skin grafts. Plast Reconstr Surg, 98(2), pp. 358-361. ISSN: 0032-1052

Yang G, Chen B, Gao Y, Liu X, Li J, Jiang S \& He S. (1981). Forearm free skin flap transplantation. Natl Med J China, 61:139-141. ISSN: 0376-2491. 


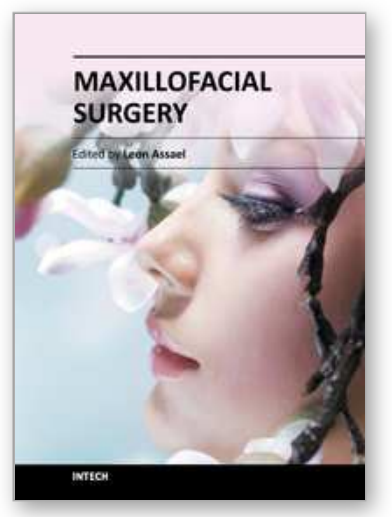

\author{
Maxillofacial Surgery \\ Edited by Prof. Leon Assael
}

ISBN 978-953-51-0627-2

Hard cover, 86 pages

Publisher InTech

Published online 23, May, 2012

Published in print edition May, 2012

\title{
How to reference
}

In order to correctly reference this scholarly work, feel free to copy and paste the following:

Raphael Ciuman and Philipp Dost (2012). The Forearm Flap - Indications, Appropriate Selection, Complications and Functional Outcome, Maxillofacial Surgery, Prof. Leon Assael (Ed.), ISBN: 978-953-510627-2, InTech, Available from: http://www.intechopen.com/books/maxillofacial-surgery/reconstructivesurgery-in-head-and-neck-the-forearm-flap-indications-appropriate-selection-compl

\section{INTECH}

open science | open minds

\section{InTech Europe}

University Campus STeP Ri

Slavka Krautzeka 83/A

51000 Rijeka, Croatia

Phone: +385 (51) 770447

Fax: +385 (51) 686166

www.intechopen.com

\section{InTech China}

Unit 405, Office Block, Hotel Equatorial Shanghai No.65, Yan An Road (West), Shanghai, 200040, China 中国上海市延安西路65号上海国际贵都大饭店办公楼405单元 Phone: $+86-21-62489820$

Fax: +86-21-62489821 
(C) 2012 The Author(s). Licensee IntechOpen. This is an open access article distributed under the terms of the Creative Commons Attribution 3.0 License, which permits unrestricted use, distribution, and reproduction in any medium, provided the original work is properly cited. 